\title{
Expression of Müllerian inhibiting substance type II receptor and antiproliferative effects of MIS on human cervical cancer
}

\author{
JAE YEN SONG ${ }^{1}$, HYUN HEE JO ${ }^{1}$, MEE RAN KIM ${ }^{1}$, YOUNG OAK LEW ${ }^{1}$, KI SUNG RYU ${ }^{1}$, JUNG HO CHA ${ }^{2}$, \\ CHANG SUK KANG ${ }^{3}$, PATRICIA K. DONAHOE ${ }^{4}$, DAVID T. MacLAUGHLIN ${ }^{4}$ and JANG HEUB KIM ${ }^{1}$
}

\author{
Departments of ${ }^{1}$ Obstetrics and Gynecology, ${ }^{2}$ Anatomy and ${ }^{3}$ Clinical Pathology, College of Medicine, \\ The Catholic University of Korea, Seoul, Republic of Korea; ${ }^{4}$ Pediatric Surgical Research Laboratories, \\ Massachusetts General Hospital, Harvard Medical School, Boston, MA 02114, USA
}

Received November 16, 2011; Accepted January 26, 2012

DOI: $10.3892 /$ ijo.2012.1370

\begin{abstract}
This study aimed to analyze expression of Müllerian inhibiting substance type II receptor (MISRII) protein and mRNA in cervical neoplasia, to demonstrate the growth inhibition of cervical cancer cells by administration of highly purified recombinant human Müllerian inhibiting substance (MIS) and, furthermore, to evaluate the clinical significance of MIS as a biological modifier for MIS receptor expressing tumors. Reverse transcriptase polymerase chain reaction (RT-PCR) was used for MISRII mRNA expression, and in situ hybridization and immunohistochemistry were used to observe expression, location of MISRII mRNA and protein, respectively. To demonstrate the effect of MIS on the viability of cervical cancer cells, methyl thiazole tetrazolium (MTT) assay was performed. Flow cytometry was used to evaluate the cell cycle distribution after exposure to MIS in cervical cancer cells, and the annexin-VFITC staining method was performed to demonstrate apoptosis by MIS in cervical cancer cells. Expression of MISRII protein and mRNA were observed in all normal cervical and cervical carcinoma tissues. There was no significant difference in expression of MISRII protein and MISRII mRNA between normal cervical and cervical carcinoma tissues. MTT assay showed negative correlation between MIS exposure time and the viability of cervical cells $(\mathrm{P}=0.008)$. The changes in cell cycle distribution after MIS exposure suggest that MIS plays an important role in inducing cellular apoptosis by causing arrest at the $\mathrm{G}_{1}$ phase and increasing cells at sub- $\mathrm{G}_{0} \mathrm{G}_{1}$ phase. Annexin-V-FITC staining methods showed that cellular apoptosis was, respectively, 10.44 and $12.89 \%$ after 24 and $48 \mathrm{~h}$ of MIS exposure in cervical carcinoma cells. There was a negative correlation between cellular survival and MIS exposure time. This study demonstrates that
\end{abstract}

Correspondence to: Dr Jang Heub Kim, Department of Obstetrics and Gynecology, Catholic University of Korea, 505 Banpo-dong, Seocho-gu, Seoul 137-701, Republic of Korea

E-mail: janghkim@catholic.ac.kr

Key words: Müllerian inhibiting substance, anti-Müllerian hormone, Müllerian inhibiting substance type II receptor, cervical cancer, immunohistochemistry, in situ hybridization
MISRII is present on normal cervical and cervical carcinoma tissues, and MIS shows receptor-mediated antiproliferative effect on cervical cells in vitro. These data suggest that MIS may be used as a biological modifier or therapeutic modulator on MISRII-expressing tumors in the future.

\section{Introduction}

In 1946, Alfred Jost observed that the regression of the Müllerian duct in the rabbit embryo was not due to testosterone after removing undifferentiated gonad and inserting testosterone crystals in its place. He named the critical agent produced by testis, Müllerian inhibiting substance (MIS) (1), also known as anti-Müllerian hormone (AMH). Following the discovery, an in vitro MIS bioassay was developed (2), bovine MIS was purified (3) and an immunoassay was created employing monoclonal antibody (4). The human gene was cloned and recombinant human MIS (rhMIS) was purified (5) soon thereafter a human specific ELISA came to use (6-8). MIS is a 140-kilodalton (kDa) glycoprotein homodimeric glycoprotein that is a member of TGF- $\beta$ multigene family (9). The human MIS gene is on short arm of chromosome 19 the encoded protein produces a $25-\mathrm{kDa}$ carboxy-terminus by proteolytic cleavage. This domain is sufficient to induce Müllerian duct regression in vitro, whereas $110 \mathrm{kDa}$ amino-terminal extends the half-life of MIS (10) and may facilitate MIS activity. The MIS receptor is expressed in all tissues of Müllerian duct origin. It is a heterometric complex consisting of single membrane spanning type I and II serine threonine kinases. The MIS carboxy-terminus binds to a unique MISRII which in turn phosphorylates one of several MIS type I receptors and produces signal transduction via a cascade of the intracellular Smad pathway originally found to be used in BMP signaling $(11,12)$. Other studies suggest that MIS inhibits the cell growth by different cellular signaling pathways involving cyclin-dependent kinase inhibitor (CDKI) $(19,22,23)$ or nuclear factor- $\mathrm{KB}(\mathrm{NF} \mathrm{K})$ (13). In addition to being an inhibiting factor associated with sex differentiation and reproductive physiology, the MIS receptor was identified in tissues other than the reproductive system, therefore, MIS could be a multifunctional cellular modulator (14).

MIS is produced by the embryonic testes and responsible for the regression of the Müllerian duct by binding the receptor 
in mesenchyme surrounding the Müllerian duct. Thus blocking its differentiating into the oviduct, uterus, upper vagina and the outer lining of the ovary. MIS is also associated with fetal lung maturation (15), and differentiation of the ovary and testis (16). The serum concentration of MIS is $10-70 \mathrm{ng} / \mathrm{ml}$ in neonatal boys, it slightly elevates before puberty then declines after puberty, and maintains a level of $2-5 \mathrm{ng} / \mathrm{ml}(6,17)$. In females, MIS is not produced by the ovarian granulosa cells to measurable levels in serum or follicular fluids until after puberty. The concentration of MIS in females is similar to male $(2-5 \mathrm{ng} / \mathrm{ml})$. In postmenopausal woman, MIS is not produced. This allows it to be used as a parameter of an ovarian function $(6,9,17)$. In addition, MIS regulates recruitment and maturation of follicle, folliculogenesis and acts as an inhibiting factor of steroid hormone production, in autocrine, paracrine and endocrine manner $(9,17)$. MIS not only inhibits differentiating into the oviduct, uterus and upper vagina in male, but also inhibits meiosis of oocyte in late prophase from 3 days afterbirth to puberty before ovulation in female. In male, MIS inhibits meiosis of germ cell in prophase, although varying in degree according to the timing. MIS acts as a regulatory factor of cell division both in male and female $(16,18)$. MIS-deficient male mice had Leydig cell hyperplasia and hyperandrogenism while MIS-deficient female mice showed accelerated oocyte degenration and increased follicular atresia (16,18-21).

Not only is MIS an inhibiting factor of a sexual development and reproductive physiology, it is established as a regulator of cell growth. After MIS was proposed as possible tumor growth suppressor, it has been investigated intensively, since the early 1980 's. The ovarian surface epithelium morphologically simulates the lining cells of the fallopian tube, which are derivatives of the coelomic epithelium of the urogenital ridge, which invaginates to form a Müllerian duct early in embryonic life (11). Several studies provide physiologic confirmation of the Müllerian origin of serous ovarian tumors and suggest that MIS may ultimately prove to be effective in its therapy. The results of the studies presented show that the growth of ovarian tumor cell lines and ovarian tumors were suppressed by MIS concentration, especially effective in highly purified rhMIS (22-25).

It has also been demonstrated in previous studies that proliferation of cervical, endometrial and breast cancer cells are suppressed by MIS treatment $(13,26,27)$. Many of these studies mentioned the potential of MIS as a treatment of MIS-receptor expressing tumors, however, in-depth discussion or investigation has yet to come (14). MIS inhibits proliferation of cervical cancer cell lines (CaSki, SiHa, C33A) (26). Previously, we demonstrated the expression of MIS type II receptor (MISRII) in the human papilloma virus (HPV)-16 related cervical cancer cell lines (CaSki, SiHa) and a non-HPV-related cervical cancer cell line (C33A) (28). We also showed that MIS inhibited growth of cervical cancer cells, and induced cellular apoptosis of C33A. In addition, we identified characteristic molecular signature of MIS in CaSki cells by using whole genome expression analysis (28). However, evidenced based data on the potential benefit of MIS against human cervical cancers requires further study.

Therefore, this study is aimed to analyze expression of MISRII protein and mRNA in cervical neoplasia, to demonstrate the growth inhibition of cervical cancer cells by administration of highly purified MIS, and, furthermore, to evaluate the clinical significance of MIS as a biological modifier for MIS receptor expressed tumors.

\section{Materials and methods}

Clinical specimens. Paraffin-fixed 12 normal cervical tissues and 30 cervical cancer tissues (6 squamous cell carcinoma in situ, 2 microinvasive squamous carcinoma, 11 squamous cell carcinoma, 2 adenocarcinoma in situ, 2 microinvasive adenocarcinoma, 7 adenocarcinoma) were obtained through St Mary's Hospital Tissue Banks in the Clinical Pathology Department from September 2006 to May 2010. Fifteen fresh human tissues (4 normal cervical tissue, 9 squamous carcinoma, 2 adenocarcinoma) were obtained from discarded tissues of patients undergoing surgery at the hospital. Among four fresh tissues of normal cervix, there was one case infected by HPV 51. On the other hand, there were 12 cases infected by HPV 16 (7 cases), HPV 18 (2 cases), HPV 31 (1 case), HPV 33 (1 case), HPV 52 (1 case) among 11 fresh tissues of cervical cancer. One fresh tissue of squamous cancer was co-infected by HPV 16 and HPV 18. The patients ranged in age from 34 to 68 years (mean 45.4 years). This study was approved by the Institutional Review Board-Human Research Committee at the Hospital (no. SCMC07BR22). Informed consent was obtained from each patient.

Construction of tissue microarray block. For the construction of the tissue microarray block (TMB), H\&E-stained sections from all specimens were carefully reviewed. Tissue cylinders $3 \mathrm{~mm}$ in diameter were punched from carefully selected histologically representative regions of each paraffin-embedded donor tissue block and brought into a recipient paraffin block using a tissue punch instrument. In constructed TMB, clinical samples were arrayed in 5 rows $x 6$ columns position, and control samples were positioned in the 7 th column.

Tissue preparation. In order to extract the RNA for reverse transcriptase polymerase chain reaction (RT-PCR), 4 normal cervical tissues and 11 cases of cervical cancer were frozen and stored in liquid nitrogen. For in situ hybridization and immunohistochemistry, $5 \mu \mathrm{m}$-thick sections from TMB and some paraffin-embedded donor blocks were prepared on the slides (Probe on slide, Fisher Scientific Co., Pittsburgh, PA, USA).

\section{The expression of MISR II $m R N A$ by RT-PCR}

$R N A$ extraction and reverse transcription. Total RNA was isolated from 4 normal cervical tissues and 11 cases of cervical cancer using RNA tissue kit (Boehringer-Mannheim $\mathrm{GmbH}$, Mannheim, Germany). First-strand cDNA was reverse-transcribed from the total RNA using RT kit(Boehringer-Mannheim) according to the manufacturer's instruction. The each reaction mixture was as followed; 10X reverse transcription buffer $2 \mu 1$, MMLV reverse transcriptase $0.8 \mu \mathrm{l}$, dNTP mix $2 \mu \mathrm{l}, 25 \mathrm{mM}$ $\mathrm{MgCl} 4 \mu \mathrm{l}$, random hexamer $2 \mu \mathrm{l}$, RNase inhibitor $1 \mu \mathrm{l}$, total RNA $2 \mu \mathrm{g}$, and total volume was adjusted to $20 \mu \mathrm{l}$ with Depc water. The reaction mixtures were incubated for $10 \mathrm{~min}$ at $25^{\circ} \mathrm{C}$, and then for $60 \mathrm{~min}$ at $42^{\circ} \mathrm{C}$ followed by RT enzyme inactivation step for $10 \mathrm{~min}$ at $70^{\circ} \mathrm{C}$. The reaction products were then stored $-20^{\circ} \mathrm{C}$ before the next procedure.

$R T-P C R$. cDNA products were amplified using by Takara PCR amplication kit (Takara Shuzo Corp., Shiga, Japan). PCR mixture consisted of 10X PCR buffer $3 \mu \mathrm{l}$, dNTP $2.4 \mu 1$, 
downstream primer (10 pmol) $1 \mu \mathrm{l}$, upstream primer (10 pmol) $1 \mu \mathrm{l}$, Taq polymerase $0.4 \mu \mathrm{l}$, cDNA $1 \mu \mathrm{l}$, and DEPC water 21.2 $\mu$ 1. Amplication started with denaturation at $94^{\circ} \mathrm{C}$ for $4 \mathrm{~min}$ followed by 30 cycles of $94^{\circ} \mathrm{C}$ for $1 \mathrm{~min}, 58^{\circ} \mathrm{C}$ for $1 \mathrm{~min}$ and $72^{\circ} \mathrm{C}$ for $1 \mathrm{~min}$. The final extension was made at $72^{\circ} \mathrm{C}$ for $10 \mathrm{~min}$. The sequences of PCR primers were as follows; upstream primer 5'-ccetgctacagcgaaagaac-3' (MISR II cDNA; Gene Bank, accession no. AF172932; sequence 581-600), and downstream primer 5'-tgggtcaagtagtggcacag-3' (sequence 921-941). PCR products (4 $\mu \mathrm{l}$ ) were separated by electrophoresis on a $1 \%$ agarose gel, and the band size (361 bp) was examine compared with DNA ladder.

Sequencing protocol. Sequencing reactions were performed in an MJ Research PTC-225 Peltier Thermal Cycler using a ABI PRISM Big Dye Terminator Cycle Sequencing Kits with AmpliTaq DNA polymerase (FS enzyme) (Applied Biosystems, Foster City, CA, USA), following the protocols supplied by the manufacturer. Single-pass sequencing was performed on each template using primer. The fluorescent-labeled fragments were purified from the unincorporated terminators with an ethanol precipitation protocol. The samples were resuspended in distilled water and subjected to electrophoresis in an ABI 3730xl sequencer (Applied Biosystems).

Immunohistochemistry. Tissues for imunohistochemical detection of the MIS type II receptor were processed using a fast temperature-controlled machine, microprobe immunostaining station (Biomeda Co., Foster City, CA, USA). The immunostaining procedure was as follows: TMB slides were preheated at $85^{\circ} \mathrm{C}$ for $30 \mathrm{~min}$, dewaxed with xylene ( $2 \mathrm{~min}, 4$ times) and re-hydrated with water. In order to retrieve antigenic sites, the slides were autoclaved at $121^{\circ} \mathrm{C}$ for $10 \mathrm{~min}$ in citrate buffer (Zymed Lab. Inc., San Francisco, CA, USA), and cooled for $20 \mathrm{~min}$ at room temperature. The slides were then treated with $3 \% \mathrm{H}_{2} \mathrm{O}_{2}$ at $45^{\circ} \mathrm{C}$ for $5 \mathrm{~min}$ to eliminate endogenous peroxidase activity followed by T-TBS wash 4 times. After treatment with normal rabbit serum (Zymed Lab. Inc.) at $45^{\circ} \mathrm{C}$ for 5 min to block the non-specific protein binding, the slides were incubated with rabbit polyclonal anti-human MIS type II receptor antiserum (provided by Dr David T. MacLaughlin, Massachusetts General Hospital, Boston, MA, USA) as primary antiserum at $4^{\circ} \mathrm{C}$ overnight. The slides were rinsed in T-TBS 4 times, and incubated with biotinylated anti-rabbit IgG (Zymed Lab. Inc.) as the second antibody at $45^{\circ} \mathrm{C}$ for $7 \mathrm{~min}$. After T-TBS rinse 4 times, Streptavidin HRP detection system (Zymed Lab. Inc.) was applied to the slides at $45^{\circ} \mathrm{C}$ for $7 \mathrm{~min}$ to induce the biotin-avidin binding reaction. The slides were treated with 3-amino-9-ethylcarbazole (AEC) for $10 \mathrm{~min}$ at room temperature, counterstained with hematoxylin, and then mounted with glycerol gel.

\section{In situ hybridization}

Production of RNA probe for MIS type II receptor. In order to get the in situ RNA-probe, a 361-bp PCR product was prepared from the full length of human MISR cDNA (provided by Dr David T. MacLaughlin) using the above primers, and cloned into T-Easyvector (Promega Corp., Madison, WI, USA). The digoxingenin (DIG)-labeled sense and antisense human MISRII RNA-probe were prepared by in vitro transcription using a DIG RNA Labeling Kit (Boehringer-Mannheim) according to the manufacturer's protocol. Titer of RNA probe was examined using dot blot method.

In situ hybridization. Five $\mu \mathrm{m}$-thick sections from TMB were preheated at $85^{\circ} \mathrm{C}$ in oven for $30 \mathrm{~min}$, dewaxed with xylene ( 2 min, 4 times). After dewaxing, slides were rinsed with $100 \%$ alcohol, and then dried at $40^{\circ} \mathrm{C}$ in oven for $1 \mathrm{~h}$. The dried sections were treated in $0.2 \mathrm{~N} \mathrm{HCI}$ for $20 \mathrm{~min}$ and incubated in $20 \mu \mathrm{g} /$ $\mathrm{ml}$ pepsin $(0.1 \mathrm{~N} \mathrm{HCI})$ for $20 \mathrm{~min}$ at room temperature, which was followed by three washes with diethyl pyrocarbonatetreated PBS. The sections were dehydrated with ethanol and dried. Prehybridization and hybridization steps were carried out at $53^{\circ} \mathrm{C}$ for 2 and $15 \mathrm{~h}$, respectively. The prehybridization buffer was composed of $50 \%$ formamide, $4 \mathrm{X} \mathrm{SSC,} 10 \%$ dextran sulfate, 1X Denhardt's solution, and $1 \mathrm{mg} / \mathrm{ml}$ salmon sperm DNA. The hybridization buffer was identical to the prehybridization buffer except that salmon sperm DNA was substituted with $200 \mathrm{ng} / \mathrm{ml}$ MISR II riboprobe. After post-hybridization washing, sections were incubated with anti-digoxigenin antiserum conjugated with alkaline phosphatase (BoehringerMannheim), and histochemical detection was then performed using 4-nitroblue tetrazolium and 5-bromo-4-chloro-3-indolylphosphate (Boehringer-Mannheim).

Cervical cancer cell culture and addition of MIS. Fresh human uterine cervix cancer specimens were processed as quickly as possible after collection. The tissues were rinsed twice with phosphate-buffered saline (PBS) and were cut into $~ 1-3$ $\mathrm{mm}^{3}$ sized pieces. The portions of minced tumor were then placed into $50 \mathrm{ml}$ conical tube containing $20 \mathrm{ml}$ of enzyme solution [0.14\% collagenase type I (Sigma, St. Louis, MO, USA) and 0.01\% DNaseI (Sigma, 20,000 U/mg) in Dulbecco's modified Eagle's medium (Gibco, Grand Island, NY, USA)], and incubated on a magnetic stirring apparatus for $2 \mathrm{~h}$ at $37^{\circ} \mathrm{C}$. Enzymatically dissociated tumor was then filtered through $100 \mathrm{~mm}$ nylon mesh to generate a single cell suspension. The resultant cell suspension was then washed twice in Dulbecco's modified Eagle's medium (Gibco) containing $10 \%$ fetal bovine serum (FBS), $100 \mathrm{U} / \mathrm{ml}$ penicillin and 100 $\mathrm{U} / \mathrm{ml}$ streptomycin. The pieces were subsequently incubated at $37^{\circ} \mathrm{C}$ in humid air with $5 \% \mathrm{CO}_{2}$. rhMIS (71 $\left.\mathrm{nM}\right)$ was added on the cervical cancer cell cultures.

The measurement of cell viability by MTT assay. Three thousand cells/well were seeded in 96-well plates (Costar, Cambridge, MA, USA) in DMEM with $10 \%$ FBS. After 24 h the cells were exposed to $71 \mathrm{nM}$ of MIS for 24 and $48 \mathrm{~h}$. The treated cells were washed with PBS and $100 \mu \mathrm{l}$ of MTT solution $(5 \mathrm{mg} / \mathrm{ml}$ MTT stock in PBS diluted to $1 \mathrm{mg} / \mathrm{ml}$ with $10 \%$ DMEM) was added to each well. Cells were incubated for $4 \mathrm{~h}$ at $37^{\circ} \mathrm{C}$ at the end of which time $200 \mu \mathrm{l}$ DMSO (Sigma) was added and incubated further for $30 \mathrm{~min}$ at room temperature in the dark. Optical densities at $550 \mathrm{~nm}$ were measured using an ELISA plate reader (Bio-Tek Instruments, Winooski, VT, USA).

Cell cycle analysis. Cells were exposed to MIS for 24 and $48 \mathrm{~h}$, collected by trypsinization, fixed with methanol and stored for $30 \mathrm{~min}$ at $20^{\circ} \mathrm{C}$ with the equivalent volume of PBS ( $\mathrm{pH} \mathrm{7.4)}$ vehicle control. The cells were washed with PBS and resuspended in $1 \mathrm{ml}$ DNA staining solution $(20 \mu \mathrm{g} / \mathrm{ml}$ propidium 


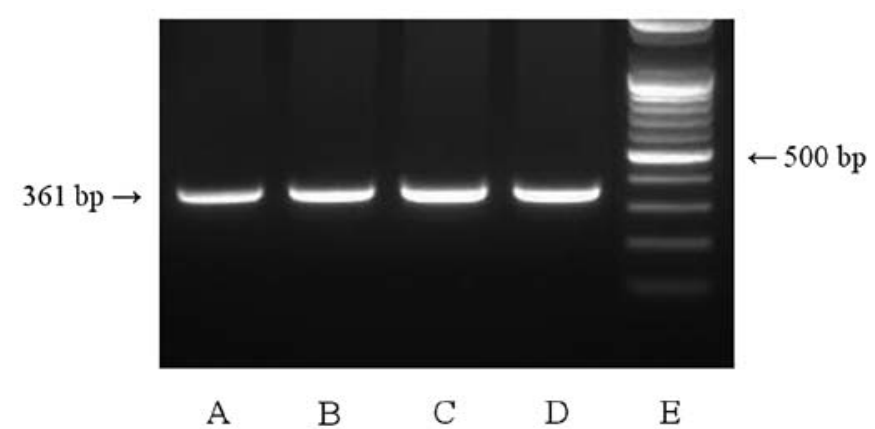

Figure 1. RT-PCR of human MISRII mRNA from human cervix and cervical cancers. Bands of 361 bp are detected in normal cervix (A and B), squamous cell carcinoma of cervix (C), and adenocarcinoma of cervix (D). Lane $\mathrm{E}$ is the DNA ladder.

iodide, $200 \mu \mathrm{g} / \mathrm{ml}$ DNase free RNase) and incubated in the dark at $37^{\circ} \mathrm{C}$ for $30 \mathrm{~min}$. The cells were analyzed on a FACSVatage SE flow cytometer (Becton-Dickison, San Jose, CA, USA). The results were analyzed using Cell Quest ${ }^{\mathrm{TM}}$ software and Modfit LT 3.0 program (Verity Software House, Topsham, ME, USA).
Annexin-Vanalysis. MIS treated cells were stained for annexin- $\mathrm{V}$ and propidium iodide (PI) using the Annexin-V-FITC Apoptosis Detection Kit I (BD Biosciences, San Diego, CA, USA) according to the manufacturer's protocol. Briefly, following drug treatment, $1 \times 10^{5}$ cells were pelleted and washed once with PBS and resuspended in $100 \mathrm{ml}$ of binding buffer [10 mM HEPES (pH 7.4), $150 \mathrm{mM} \mathrm{NaCl}, 5 \mathrm{mM}$ potassium chloride, $1 \mathrm{mM}$ $\mathrm{MgCl}_{2}$, and $2 \mathrm{mM}$ calcium chloride]. Subsequently, $5 \mu \mathrm{l}$ of annexin V-FITC and PI was added to the cells that were then incubated for $15 \mathrm{~min}$ at room temperature in the dark. After incubation, $400 \mu 1$ of binding buffer was added to the stained cells, and cells were analyzed using a FACSVatage SE Flow Cytometer (Becton-Dickison). Data analysis was conducted using Cell Quest ${ }^{\mathrm{TM}}$ software.

Expression scoring system and statistical analysis. The intensity of immunohistochemistry and in situ hybridization staining were assessed independently by 2 pathologists on a scale of increasing intensity, 0 (no staining), 1 (weak), 2 (moderate), and 3 (strong staining). Data were analyzed by using Wilcoxon rank sum test and Wilcoxon signed rank test. A $\mathrm{P}<0.05$ was considered statistically significant.
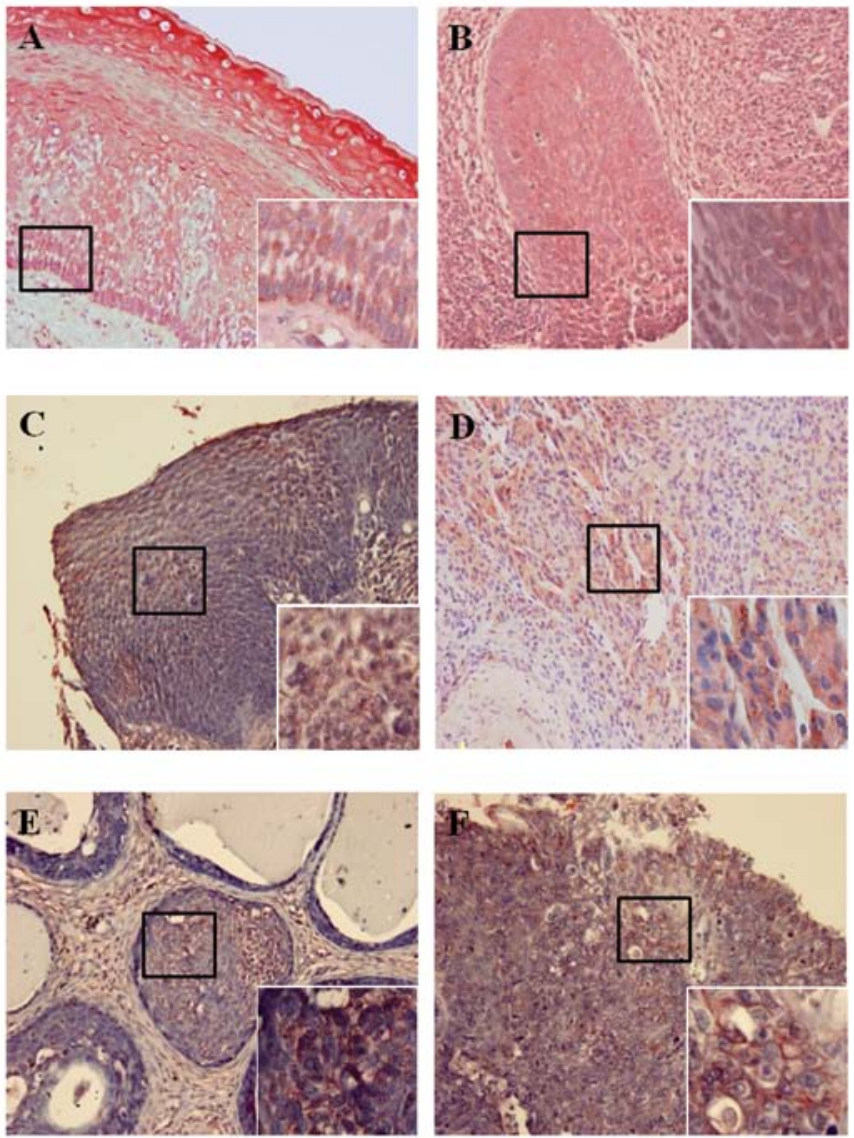
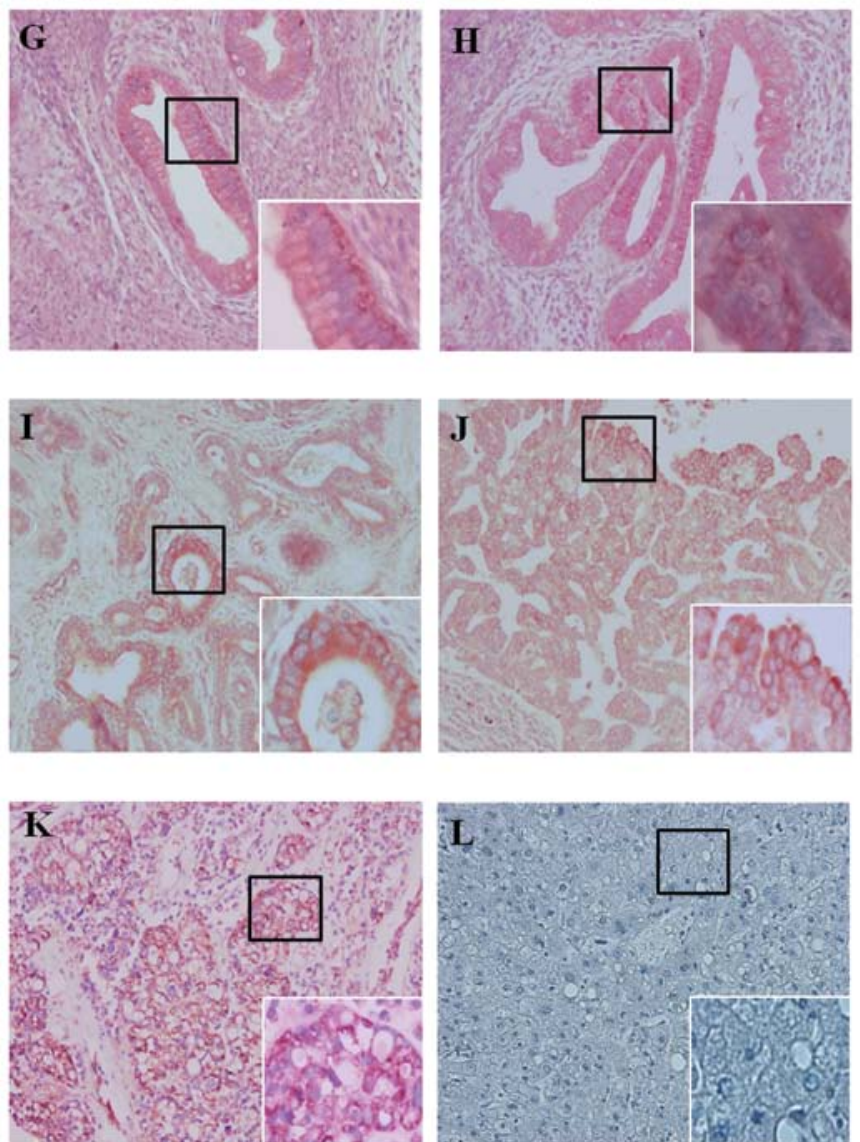

Figure 2. Light micrography of human uterine cervix. (A) The squamous epithelium moderately express MISRII in the cell membrane. In this and all subsequent panels, the right lower boxed area is of higher magnification (x400). Chromogen, AEC. Magnification x200. (B) In carcinoma in situ (CIS) of the cervix cells moderately express MISRII. (C) Microinvasive squamous cell carcinoma of the cervix moderately express MISRII in the cell membrane. (D) Squamous cell carcinoma, well differentiated of uterine cervix. moderately express MISRII in the cell membrane. (E) Moderately differentiated carcinoma of uterine cervix moderately expresses MISRII. (F) Poorly differentiated cells moderately express MISRII. (G) Human adenocarcinoma in situ (AIS) strongly express MISRII. (H) Microinvasive adenocarcinoma diffusely and strongly express MISRII. (I) Adenocarcinoma, well differentiated diffusely and strongly express MISRII. (J) Adenocarcinoma, moderately differentiated diffusely and strongly express MISRII (K) adenocarcinoma, poorly differentiated diffusely and strongly express MISRII. (L) Human liver specimen used as negative control. No immunoreactivity for MISRII is detected. 

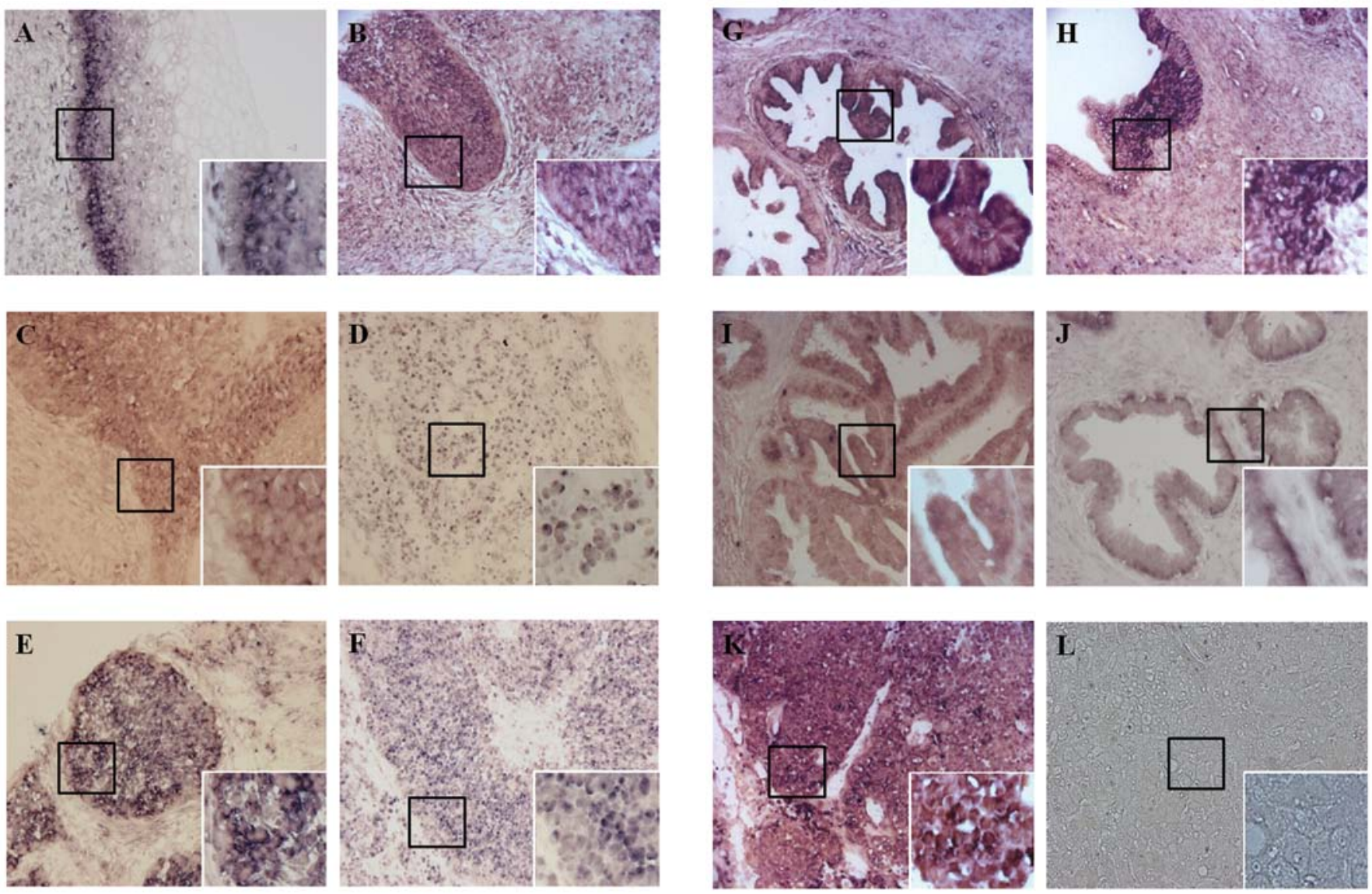

Figure 3. Light micrography from human uterine cervix (A) show strong expression for MISRII mRNA in the squamous epithelium. In this and all subsequent panels, the right lower figure is higher magnification of the boxed area $(\mathrm{x} 400)$. Chromogen, 4-nitroblue tetrazolium chloride/5-bromo-4-chloro-3-indolyl-phosphate (NBT/BCIP). Magnification x200. (B) CIS of uterine cervix diffusely and strongly express MISRII mRNA. (C) Microinvasive squamous cell carcinoma moderately express MISRII mRNA. (D) Squamous cell carcinoma, well differentiated diffusely and moderately expresses MISRII mRNA. (E) Light micrography from human squamous cell carcinoma, moderately differentiated of uterine cervix. The cancer cells diffusely and strongly express MISRII mRNA. (F) Light micrography from human squamous cell carcinoma, poorly differentiated of uterine cervix. The cancer cells diffusely and strongly express MISRII mRNA. (G) Light micrography from human AIS of uterine cervix. The cancer cells diffusely and strongly express MISRII mRNA. (H) Light micrography from human microinvasive adenocarcinoma of uterine cervix. The cancer cells diffusely and strongly express MISRII mRNA. (I) Human adenocarcinoma well differentiated cells diffusely and moderately express MISRII mRNA. (J) Adenocarcinoma moderately differentiated diffusely and moderately express MISRII mRNA. (K) Adenocarcinoma, poorly differentiated cells diffusely and strongly express MISRII mRNA. (L) Human liver specimen used as negative control. No in situ signal for MISRII is shown.

\section{Results}

Expression of MISRII mRNA by RT-PCR. We analyzed MISR II mRNA expression in 2 normal cervical tissues, a squamous cell carcinoma of cervix, and an adenocarcinoma of cervix by RT-PCR and all tissues showed 361 bp band which was confirmed to be identical to a segment of human MISR II cDNA sequence (581-941) (Gene Bank, accession no. AF172932) (Fig. 1).

Expression of MISRII protein by immunohistochemistry. In all twelve normal human uterine cervical samples, the squamous epithelium moderately express MISR II protein in the cell membrane $(2.33 \pm 0.19)$ (Fig. 2A). The cancer cells in cervical carcinoma in situ (6 cases) moderately express MISR II protein $(2.17 \pm 0.31)$ (Fig. 2B). The cancer cells in microinvasive cervical squamous carcinoma ( 2 cases) moderately express MISR II

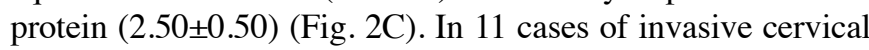
squamous carcinoma, the cancer cells diffusely and moderately express MISR II protein in the cell membrane with similar intensity according to cancer differentiation (2.27 \pm 0.19$)$ (Fig. 2D-F).
In adenocarcinoma in situ ( 2 cases) and microinvasive adenocarcinoma ( 2 cases), the cancer cells strongly express MISR II protein (2.50 \pm 0.5 and $2.50 \pm 0.5$, respectively) (Fig. $2 \mathrm{G}$ and $\mathrm{H}$ ). In adenocarcinoma ( 7 cases), the cancer cells strongly express MISR II protein in the cell membrane with similar intensity according to cancer differentiations (2.43 \pm 0.20$)$ (Fig. 2I-K). In human liver specimen, negative control for MISR II immunostain, no immunoreactivity is detected (Fig. 2L).

Expression of MISRII mRNA by in situ hybridization. In all twelve normal human uterine cervical samples, the squamous epithelium moderately express MISR II mRNA in the cell membrane (2.25 \pm 0.18$)$ (Fig. 3A). The cancer cells in cervical carcinoma in situ (6 cases) moderately express MISR II mRNA $(2.50 \pm 0.22)$ (Fig. 3B). The cancer cells in microinvasive cervical squamous carcinoma ( 2 cases) moderately express MISR II mRNA (2.00 \pm 0.00$)$ (Fig. 3C). In 11 cases of invasive cervical squamous carcinoma, the cancer cells diffusely and moderately express MISR II mRNA in the cell membrane with similar intensity according to cancer differentiation $(2.27 \pm 0.14)$ (Fig. 3D-F). In adenocarcinoma in situ ( 2 cases) and microinvasive adeno- 


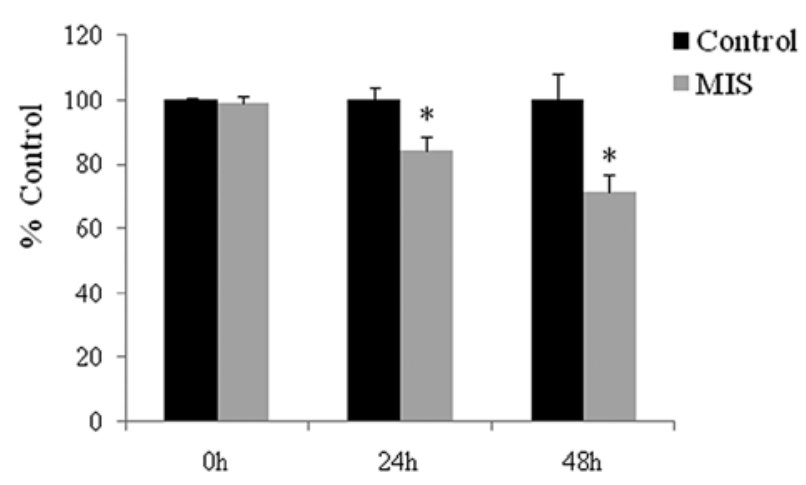

Figure 4. Effect of MIS on the viability of the cervical cancer cells. Cells were treated with $71 \mathrm{nM}$ MIS at $24 \mathrm{~h}$ after plating. At 24 and $48 \mathrm{~h}$ after treatment, cells were incubated with MTT, and the absorbance was read at $550 \mathrm{~nm}$. Results are presented as percentage of control which was calculated using the equation: (mean absorbance of treated cells/mean absorbance of control cells) $\mathrm{x}$ 100. Data are expressed as mean \pm standard deviation (SD) from 5 independent experiments. ${ }^{~} \mathrm{P}<0.01$ as compared to corresponding control cells.

carcinoma ( 2 cases), the cancer cells strongly express MISR II mRNA ( $2.50 \pm 0.5$ and $2.50 \pm 0.5$, respectively) (Fig. $3 \mathrm{G}$ and $\mathrm{H}$ ). In adenocarcinoma ( 7 cases), the cancer cells strongly express MISR II mRNA in the cell membrane with similar intensity according to cancer differentiation (2.28 \pm 0.18$)$ (Fig. 3I-K). In human liver specimen, used as negative control, no in situ signal is shown (Fig. 3L).

Effect of MIS on the viability of cervical cancer cells. Cells were treated with $71 \mathrm{nM}$ MIS at $24 \mathrm{~h}$ after plating. At 24 and $48 \mathrm{~h}$ after rhMIS treatment, cells were incubated with MTT, and the absorbance was read at $550 \mathrm{~nm}$ (Fig. 4). At 24 and $48 \mathrm{~h}$ after treatment of $71 \mathrm{nM}$ MIS, the viability of the cervical cancer cells decreased significantly to $84.51 \pm 4.04 \%$ ( $\mathrm{P}<0.01)$ and $71.63 \pm 5.13 \%(\mathrm{P}<0.01)$, respectively. MTT assay showed negative correlation between the MIS exposure time and the viability of cervical cells $(\mathrm{P}=0.008)$.

Cell cycle distribution after exposure to MIS in cervical cancer cells. In order to find out the changes in cell cycle distribution after MIS exposure, cells were treated with $71 \mathrm{nM}$ MIS for 24 and $48 \mathrm{~h}$ and histograms of cellular DNA content were obtained by flow cytometry (Fig. 5). In control incubations the proportion of cellular DNA of $\mathrm{G}_{0} \mathrm{G}_{1}, \mathrm{~S}, \mathrm{G}_{2} \mathrm{M}$ and sub- $\mathrm{G}_{0} \mathrm{G}_{1}$ phase was $46.43,23.83,26.49$ and $3.25 \%$, respectively. At $24 \mathrm{~h}$ after treatment with MIS, the proportions were 48.43, 19.09, 22.14 and $10.34 \%$, respectively.

The proportion of cellular DNA of $\mathrm{G}_{0} \mathrm{G}_{1}, \mathrm{~S}, \mathrm{G}_{2} \mathrm{M}$ and sub- $\mathrm{G}_{0} \mathrm{G}_{1}$ phase in controls for the $48 \mathrm{~h}$ MIS exposure experiment were 47.08, 23.20, 25.21 and $4.51 \%$, respectively. At $48 \mathrm{~h}$ after treatment with MIS, the proportions were 52.43, 14.95, 19.55 and $13.07 \%$. In short, the changes in cell cycle distribution after MIS exposure at 24 and $48 \mathrm{~h}$ demonstrated that $\mathrm{S}$ and $\mathrm{G}_{2} \mathrm{M}$ phases were shortened, $\mathrm{G}_{0} \mathrm{G}_{1}$ and sub- $\mathrm{G}_{0} \mathrm{G}_{1}$ phases were lengthened. Therefore, MIS plays an important role in inducing cellular apoptosis by causing arrest at G1 phase and increasing cells at sub- $\mathrm{G}_{0} \mathrm{G}_{1}$ phase.

Induction of apoptosis by MIS in cervical cancer cells. Cells were treated with $71 \mathrm{nM}$ MIS for 24 or $48 \mathrm{~h}$. For apoptosis, the externalization of phosphatidylserine was assessed by measuring annexin-V-FITC binding using propidium iodide as a counterstain (Fig. 6). The proportion of surviving cells/ early apoptotic cells/late apoptotic cells and necrotic cells on annexin-V-FITC staining were 92.13/1.78/1.04\% in controls and changed to $78.85 / 10.44 / 6.32 \%$ after $24 \mathrm{~h}$ with treatment of MIS.
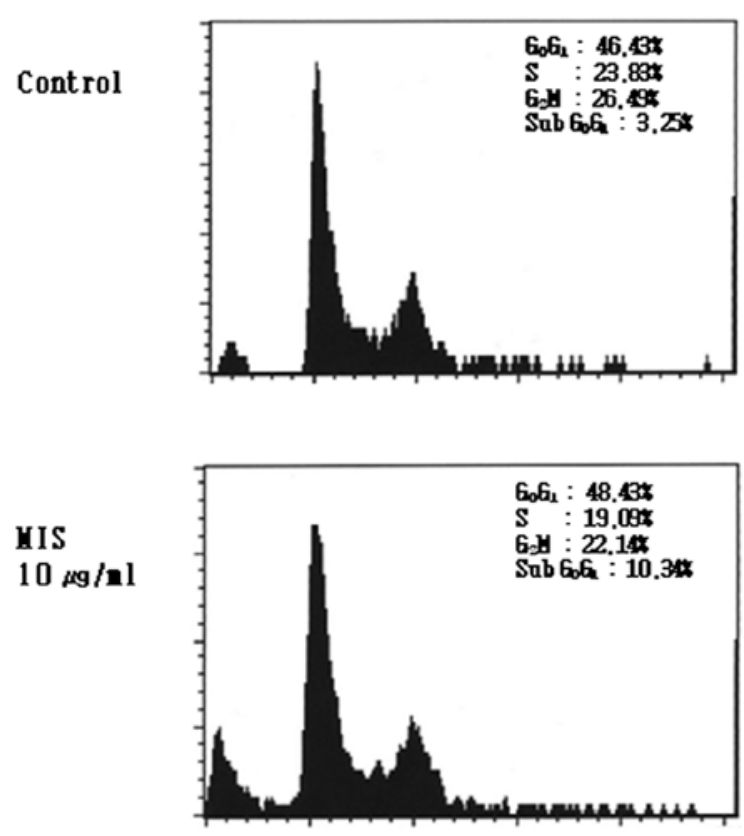

24 hours
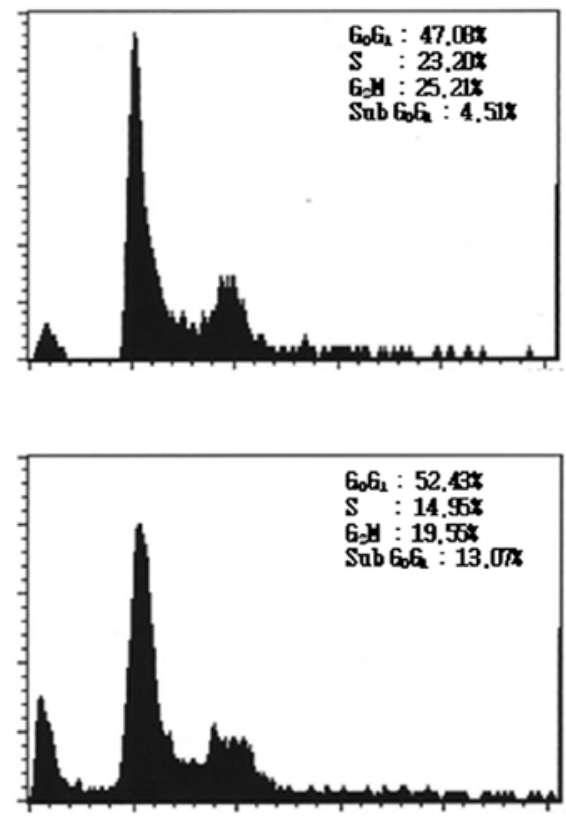

48 hours

Figure 5. Cell cycle distribution after exposure to MIS in cervical cancer cells. Cells were treated with $71 \mathrm{nM}$ MIS for 24 and $48 \mathrm{~h}$, respectively. They were trypsinized and fixed in $100 \%$ methanol. After washing, cells were exposed to propidium iodide/RNase solution. Histograms of cellular DNA content were obtained by flow cytometry. 

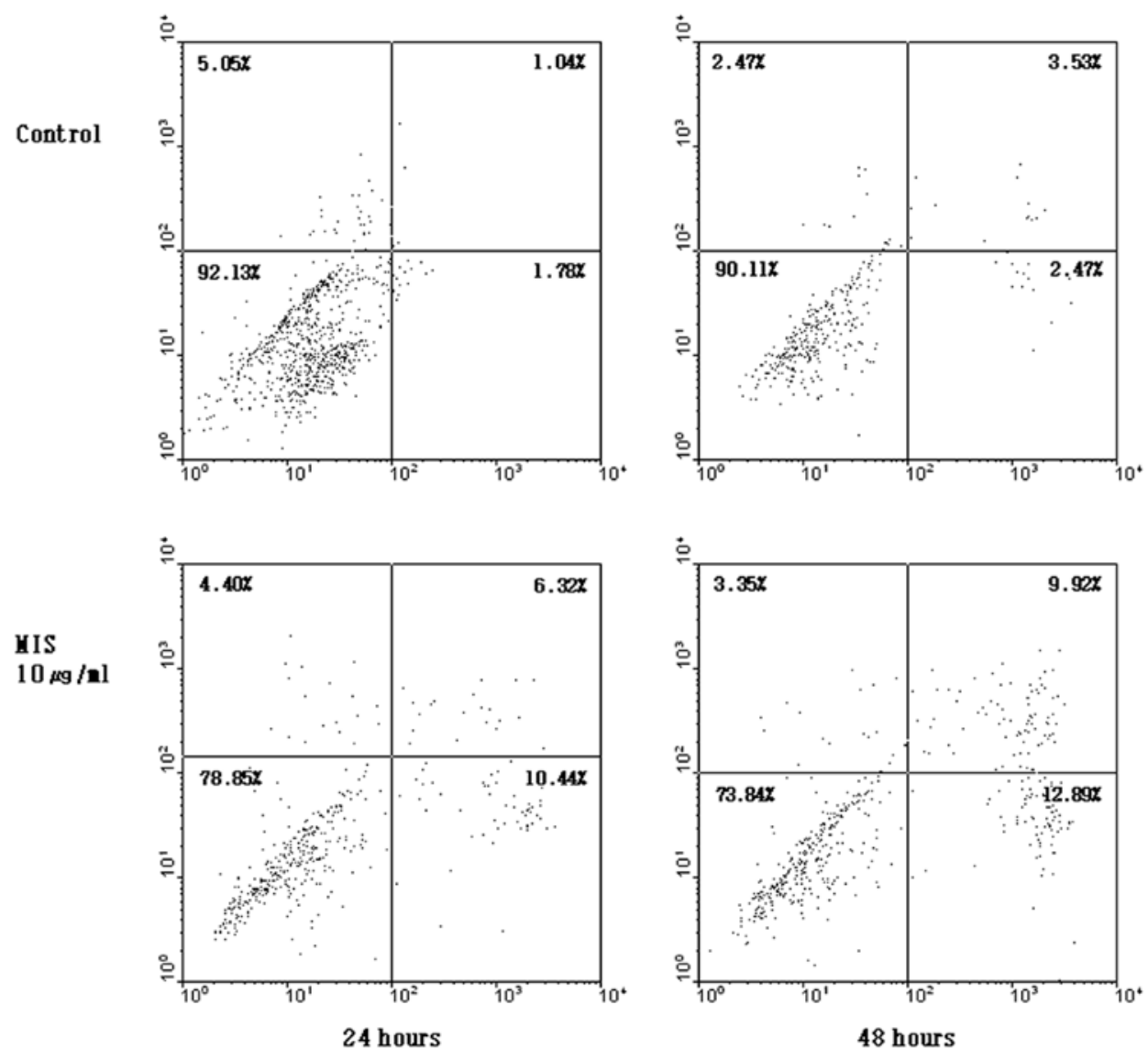

Figure 6. Induction of apoptosis by MIS in cervical cancer cells. Cells were treated with $71 \mathrm{nM}$ MIS for 24 and $48 \mathrm{~h}$, respectively. For apoptosis, the externalization of phosphatidylserine was assessed by measuring annexin-V-FITC binding using propidium iodide as a counterstain. Quadrant rectangular dot grams from a representative of 3 independent experiments are shown.

The proportions were $90.11 / 2.47 / 3.53 \%$ in control and changed to $73.84 / 12.89 / 9.92 \%$ after $48 \mathrm{~h}$, respectively. Annexin-V-FITC staining method showed that cellular apoptosis was 10.44 and $12.89 \%$ after 24 and $48 \mathrm{~h}$ of MIS exposure in cervical carcinoma cells. There was a negative correlation between cellular survival and MIS exposure time.

\section{Discussion}

A considerable body of in vitro and in vivo animal evidence supports the conclusion that recombinant human MIS may affect cancer cell growth, particularly those originating from Müllerian tissue including endometrial, cervical, fallopian tubal, and ovarian, perhaps even cancer stem cells $(13,14,22-37)$. Data presented in the current study confirm and extend the fact that human cervical cancers are also potential MIS targets. The usual treatment of malignant female reproductive tract tumors of surgery followed by chemotherapy or radiation therapy has resulted in serious systemic toxicities including induced infertility. Additionally, relapse is common due to drug resistance. Because MIS mechanism is different from the traditional chemotherapy, MIS treatment combined with chemotherapy holds promise in controlling the tumor size more effectively, with lower dose of chemotherapy agent, leading to less systemic toxicity, decreasing the prevalence of the disease, and widening the optimal therapeutic dose range of the chemoagent (26). Moreover, as seen in granulosa cell tumor patients, high MIS concentration up to 1000 -fold of normal adult female and over 70-fold concentration in normal male infant are noted without adverse effect. Therefore, unlike chemotherapy or radiation therapy, high concentrations of MIS are expected to be nontoxic, when MIS only or MIS combined with chemotherapy is administered $(14,25)$.

It is noteworthy that our study shows, for the first time, the expression pattern of MISRII protein and mRNA in various cervical carcinomas. MISRII protein and mRNA expression and intensity were noted by immunohistochemistry and in situ hybridization for each tissue sample. We found complete concordance between protein and mRNA expression. Twelve normal human uterine cervical specimens were positive for the MIS receptor. We also observed that MISRII protein and mRNA were expressed by all cervical cancers (100\%). There was little difference in the intensity of expression for MISRII protein and mRNA between normal cervix and cervical cancer. Intensity of expression for MISRII protein and mRNA is nearly the same when non-invasive and invasive cervical squamous cell carcinoma and adenocarcinoma are compared. In Figs. 2 and 3 , the cancer cell nests of squamous cell carcinoma diffusely and moderately express MISR II protein and mRNA in the cell membrane, but the cancer cells of adenocarcinoma express somewhat strong intensity. There is tendency for increased receptor protein levels in adenocarcinoma compared to squamous cell carcinoma, but it does not reach statistical significance. There were slight differences in the intensity of expression for 
MISR II protein and mRNA according to the differentiation of cervical cancer. Our data on cervical cancer is comparable with previously published studies on ovarian cancer, however, the results on the frequency of expression of MISRII in our study on cervical cancer are higher $(100 \%)$ than those previously reported $(69-89 \%)$ in ovarian cancer $(22,33,34)$. This apparent high rate of receptor positivity in cervical cancers makes the idea plausible that using MIS as a treatment may be offered to the majority of the cases. We emphasize that all human cervical carcinoma tissues express MISRII and intensities of MISR II protein and mRNA expression show only slight differences according to cell type or differentiation of cervical cancer. Expression of MISR II protein and mRNA is shown in all of normal cervical tissues and cervical cancer tissues in this study, therefore MIS may also be an effective targeted therapy for cervical cancer.

Cervical cancer cell lines used in the investigation include CaSKi, SiHa cell lines, which are HPV 16-positive, HeLa, HeLa S-3, ME-180 cell lines, which are HPV 18-positive, C33A and HT3 cell lines, which are HPV-negative. C33A and HT3 cell lines are $\mathrm{Rb}$ protein inactivated caused by exon mutation. Early studies on response assessment in cervical cancer to MIS showed suppressive effect on proliferation through MIS binding to cervical cancer HeLa S-3 cell surface (35). MIS treatment on HT-3 cell line represented $47 \%$ of suppressive effect on proliferation through colony inhibition assay (36). MISRII (63 kDa) was expressed in all CaSki, SiHa, C33A cell lines, and MTT assay after MIS treatment showed that suppressive effect on proliferation was the greatest in C33A with 70-80\% suppression, followed by 30-40\% in CaSki, and least in SiHa cell line (26). In our previous study, MISRII was expressed in $\mathrm{CaSki}, \mathrm{SiHa}$, and C33A cell lines, and MTT assay after MIS treatment showed that suppressive effect on proliferation was $28-43,15-24$ and $7-11 \%$ in C33A, CaSki and SiHa cell line, respectively (28). Furthermore, when transfected C33A was treated with inactive MIS, there was no significant decrease in cell line colony, however, when treated with active MIS, C33A colony was markedly decreased (90-95\% decrease) (26). Similarly, in treatment with TGF- $\beta(5 \mu \mathrm{g} / \mathrm{ml})$ on cervical cell line, HPV-negative HT-3 cells showed 70\% suppression, HPV 18-positive HeLa showed 25-50\% suppression in cell proliferation, whereas, little decrease was observed in HPV 16-positive CaSki, and SiHa cell lines. No suppression was seen in HPV-negative C33A and HPV 18-positive HeLa S-3, and ME-180 (37,38). Likewise, suppressive effects of MIS on ovarian cancer cell line also differ with HPV infection. The suppression effect of MIS is more significant in OVCAR8, ovarian epithelial cancer cell line which is not associated with HPV, compared to human ovarian cancer cell line HOSE 6-3, which is immortalized by HPV tumor proteins E5, and E7 (23). Overall, the anti-proliferative effect of MIS is more effective in HPV-negative cells whereas, it is limited in HPV-positive cells. Also the suppressive effect differs between various HPV types. Since HPV is established as a strong risk factor in cervical carcinoma, and most of cervical cancer patients are associated with HPV infection, the presence of HPV infection has an important role in the treatment effect of MIS and its TGF- $\beta$ superfamily. In our experiments, MIS-treated human carcinoma cells achieved in vivo showed negative correlation between the MIS exposure time and the viability of cervical cells which is consistent with other experiments. When HPV 16, 18, 31, 33, 52, 58-positive cervical cancer cells were treated with $71 \mathrm{nM}$ MIS for 24 and $48 \mathrm{~h}$, anti-proliferative effect was seen in 15.5 and $28.4 \%$, respectively. This finding corresponds with results (suppression up to 30-40\%) in HPV 16-positive CaSki cell line by Babie et al (26), and those (suppressed up to 15-24\%) of our previous study (28). Furthermore, the infected rate and distribution of HPV type in this study were similar with meta-analysis in Korea women (39). HPV goes through various stages to change $\mathrm{Rb}$ family related mechanisms, which decrease MIS effect on HPV infected cervical cancer $(26,28,40)$. Thus, MIS will have a more potent anti-proliferative effect in cervical cancer cells which are non-HPV infected or low risk HPV-related.

According to our experiment in cell cycle distribution data after exposure to MIS in cervical cancer cell, $\mathrm{S}$ and $\mathrm{G}_{2} \mathrm{M}$ phases were shortened and $\mathrm{G}_{0} \mathrm{G}_{1}$ and sub $\mathrm{G}_{0} \mathrm{G}_{1}$ phases were lengthened. Therefore, MIS plays an important role in $\mathrm{G}_{0} \mathrm{G}_{1}$ inducing cellular apoptosis by causing arrest at $\mathrm{G} 1$ phase and increasing cells at sub- $\mathrm{G}_{0} \mathrm{G}_{1}$ phase. This finding corresponds with results of our previous study. In C33A cells, the sub- $\mathrm{G}_{0} \mathrm{G}_{1}$ and $\mathrm{G}_{0} \mathrm{G}_{1}$ phases were increased 6 and $3 \%$ at $24 \mathrm{~h}$ and 10 and $8 \%$ at $48 \mathrm{~h}$ compared to controls, respectively. In CaSki cells, the sub- $\mathrm{G}_{0} \mathrm{G}_{1}$ and $\mathrm{G}_{0} \mathrm{G}_{1}$ phase was increased 3 and $5 \%$ at $24 \mathrm{~h}$ and 6 and $8 \%$ at $48 \mathrm{~h}$ compared to controls, respectively, but $\mathrm{SiHa}$ cells demonstrated minimal response in our previous study (28). Furthermore, annexin-V-FITC staining methods of MIS exposure in cervical carcinoma cells showed negative correlation between cellular survival and MIS exposure time.

In conclusion, MISRII is present in both normal cervix and cervical carcinoma tissues, and MIS shows receptor-mediated anti-proliferative effect on cervical cells in vitro. Thus, these data suggest that MIS may be used as a biological modifier or therapeutic modulator in MISRII-expressed tumors.

\section{References}

1. Jost A: Sur les derives Mulleriens d'embyons de lapin dex deux sexes castres a 21 jours. CR Biol 141: 135-136, 1947.

2. Picon R: Action of the fetal testis on the development in vitro of the Müllerian ducts in the rat. Arch Anat Microsc Morphol Exp 58: 1-19, 1969.

3. Budzik GP, Powell SM, Kamagata S and Donahoe PK: Mullerian inhibiting substance fractionation by dye affinity chromatography. Cell 34: 307-314, 1983.

4. Vigier B, Picard JY, Campargue J, Forest MG, Heyman Y and Josso N: Secretion of anti-Müllerian hormone by immature bovine Sertoli cells in primary culture, studied by a competition-type radioimmunoassay: lack of modulation by either FSH or testosterone. Mol Cell Endocrinol 43: 141-150, 1985.

5. Cate RL, Mattaliano RJ, Hession C, et al: Isolation of the bovine and human genes for Müllerian inhibiting substance and expression of the human gene in animal cells. Cell 45: 685-698, 1986.

6. Hudson PL, Dougas I and Donahoe PK: An immunoassay to detect human müllerian inhibiting substance in males and females during normal development. J Clin Endocrinol Metab 70: 16-22, 1990.

7. Baker ML, Metcalfe SA and Hutson JM: Serum levels of müllerian inhibiting substance in boys from birth to 18 years, as determined by enzyme immunoassay. J Clin Endocrinol Metab 70: 11-15, 1990.

8. Josso N, Legeai L, Forest MG, Chaussain JL and Brauner R: An enzyme linked immunoassay for anti-müllerian hormone: a new tool for the evaluation of testicular function in infants and children. J Clin Endocrinol Metab 70: 23-27, 1990.

9. Lee MM and Donahoe PK: Müllerian inhibiting substance: a gonadal hormone with multiple functions. Endocr Rev 14: 152-164, 1993.

10. MacLaughlin DT, Hudson PL, Graciano AL, et al: Müllerian duct regression and antiproliferative bioactivities of Müllerian inhibiting substance reside in its carboxy-terminal domain. Endocrinology 131: 291-296, 1992. 
11. di Clemente N, Jamin SP, Lugovskoy A, et al: Processing of anti-mullerian hormone regulates receptor activation by a mechanism distinct from TGF-beta. Mol Endocrinol 24: 2193 2206, 2010.

12. Josso N and di Clemente N: Transduction pathway of anti-Müllerian hormone, a sex-specific member of the TGF-beta family. Trends Endocrinol Metab 14: 91-97, 2003.

13. Segev DL, Ha TU, Tran TT, et al: Müllerian inhibiting substance inhibits breast cancer cell growth through an $\mathrm{NF \kappa B}$-mediated pathway. J Biol Chem 275: 28371-28379, 2000.

14. MacLaughlin DT and Donahoe PK: Müllerian inhibiting substance/ anti-Müllerian hormone: a potential therapeutic agent for human ovarian and other cancers. Future Oncol 6: 391-405, 2010.

15. Catlin EA, Powell SM, Manganaro TF, et al: Sex-specific fetal lung development and müllerian inhibiting substance. Am Rev Respir Dis 141: 466-470, 1990.

16. Behringer RR, Finegold MJ and Cate RL: Müllerian-inhibiting substance function during mammalian sexual development. Cell 79: 415-425, 1994

17. Lee MM, Donahoe PK, Hasegawa T, et al: Müllerian inhibiting substance in humans: normal levels from infancy to adulthood. J Clin Endocrinol Metab 81: 571-576, 1996.

18. Mishina Y, Rey R, Finegold MJ, et al: Genetic analysis of the Müllerian-inhibiting substance signal transduction pathway in mammalian sexual differentiation. Genes Dev 10: 2577-2587, 1996.

19. Durlinger AL, Kramer P, Karels B, et al: Control of primordial follicle recruitment by anti-Müllerian hormone in the mouse ovary. Endocrinology 140: 5789-5796, 1999.

20. Visser JA and Themmen AP: Anti-Müllerian hormone and folliculogenesis. Mol Cell Endocrinol 234: 81-86, 2005.

21. Visser JA, Durlinger AL, Peters IJ, et al: Increased oocyte degeneration and follicular atresia during the estrous cycle in anti-Müllerian hormone null mice. Endocrinology 148: 23012308, 2007.

22. Masiakos PT, MacLaughlin DT, Maheswaran S, et al: Human ovarian cancer, cell lines, and primary ascites cells express the human Müllerian inhibiting substance (MIS) type II receptor, bind, and are responsive to MIS. Clin Cancer Res 5: 3488-3499, 1999.

23. Ha TU, Segev DL, Barbie D, et al: Müllerian inhibiting substance inhibits ovarian cell growth through an pRb-independent mechanism. J Biol Chem 275: 37101-37109, 2000.

24. Stephen AE, Pearsall LA, Christian BP, Donahoe PK, Vacanti JP and MacLaughlin DT: Highly purified Müllerian inhibiting substance inhibits human ovarian cancer in vivo. Clin Cancer Res 8: 2640-2646, 2002.

25. Pieretti-Vanmarcke R, Donahoe PK, Szotek P, et al: Recombinant human Mullerian inhibiting substance inhibits long-term growth of MIS type II receptor-directed transgenic mouse ovarian cancers in vivo. Clin Cancer Res 12: 1593-1598, 2006.

26. Barbie TU, Barbie DA, MacLaughlin DT, Maheswaran S and Donahoe PK: Mullerian inhibiting substance inhibits cervical cancer cell growth via a pathway involving p130 and p107. Proc Natl Acad Sci USA 100: 15601-15606, 2003
27. Renaud EJ, MacLaughlin DT, Oliva E, Rueda BR and Donahoe PK: Endometrial cancer is a receptor-mediated target for Müllerian inhibiting substance. Proc Natl Acad Sci USA 102: 111-116, 2005.

28. Hwang SJ, Suh MJ, Yoon JH, et al: Identification of characteristic molecular signature of Müllerian inhibiting substance in human HPV-related cervical cancer cells. Int J Oncol 39: 811-820, 2011

29. Wang JJ, RofflerSR, Chou HH, Yin FY and Yin CS: Characterization of Mullerian inhibiting substance binding on cervical carcinoma cells demonstrated by immunocytochemistry. Tissue Cell 26: 467-476, 1994.

30. Szotek PP, Pieretti-Vanmarcke R, Masiakos PT, et al: Ovarian cancer side population defines cells with stem cell-like characteristics and Müllerian inhibiting substance responsiveness. Proc Natl Acad Sci USA 103: 11154-11159, 2006.

31. La Marca A and Volpe A: The anti-Müllerian hormone and ovarian cancer. Hum Reprod Update 13: 265-273, 2007.

32. Ball BA, Conley AJ, MacLaughlin DT, Grundy SA, Sabeur K and Liu IK: Expression of anti-Müllerian hormone (AMH) in equine granulosa-cell tumors and in normal equine ovaries. Theriogenology 70: 968-977, 2008.

33. Bakkum-Gamez JN, Aletti G, Lewis KA, et al: Müllerian inhibiting substance type II receptor (MIS/AMHIIR): a novel, tissue-specific target expressed by gynecologic cancers. Gynecol Oncol 108: 141-148, 2008.

34. Song JY, Chen KY, Kim SY, et al: The expression of Müllerian inhibiting substance/anti-Müllerian hormone type II receptor protein and mRNA in benign, borderline and malignant ovarian neoplasia. Int J Oncol 34: 1583-1591, 2009.

35. Wang JJ and Teng CS: Antibody against avian Müllerian inhibiting substance (MIS) recognizes MIS on rat Müllerian duct and human tumor cells. Proc Natl Sci Council Repub China B 13: 267-275, 1989.

36. Chin T, Parry RL and Donahoe PK: Human Müllerian inhibiting substance inhibits tumor growth in vitro and in vivo. Cancer Res 51: 2101-2106, 1991

37. Choi HH, Jong HS, Song SH, Kim TY, Kim NK and Bang YJ: p130 mediates TGF-beta-induced cell-cycle arrest in Rb mutant HT-3 cells. Gynecol Oncol 86: 184-189, 2002.

38. Kang SH, Won K, Chung HW, et al: Genetic integrity of transforming growth factor beta (TGF-beta) receptors in cervical carcinoma cell lines: loss of growth sensitivity but conserved transcriptional response to TGF-beta. Int J Cancer 77: 620-625, 1998.

39. Bae JH, Lee SJ, Kim CJ, et al: Human papillomavirus (HPV) type distribution in Korean women: a meta-analysis. J Microbiol Biotechnol 18: 788-794, 2008.

40. McCance DJ: The biology of the E7 protein of HPV-16. In: Papillomavirus Research from Natural History to Vaccines and Beyond. Campo MS (ed). Caister Academic Press, Glasgow, pp133-144, 2006. 